\title{
SCHOPENHAUER E A TOPICA ADMIRATIONIS: SOBRE A ORIGEM DA FILOSOFIA
}

\author{
M. R. Engler ${ }^{1}$
}

\begin{abstract}
Resumo: No texto A necessidade metafísica do homem, Schopenhauer elabora consideraçôes fundamentais sobre sua metafísica imanente e, na ânsia de explicar por que o homem filosofa, alia-se a uma longa tradição de pensadores que viram na admiração (thaumázein) o impulso metafísico do homem. Ele reinterpreta as duas mais famosas sentenças sobre o tema (Platão e Aristóteles) consoante o tom de sua filosofia. A origem da filosofia torna-se o resultado de fatores como a separação entre vontade e intelecto e a constataçáo de que o mundo, tal como agora é, possui caráter contingente e poderia deixar de ser. A isso se unem a contemplaçấo dos males do mundo e a consciência da finitude humana (morte). No fim, desse conjunto emergem os sistemas metafísicos e religiosos. Este artigo comenta detidamente essas ideias, mostra sua relação com os filósofos antigos através de cinco tópoi e, ao fim, tenta localizar a originalidade da concepção schopenhaueriana, a qual se baseia na reinterpretação do primeiro tópos.
\end{abstract}

Palavras-Chave: Schopenhauer. Admiração. Metafísica. Platâo. Aristóteles.

Daher sind die Alten noch unsere Lehrer in der Metaphysik. (Schopenhauer, Über das metaphysische Bedürfnis.)

\section{InTRODUÇÃo}

O presente artigo discute o ensaio de Schopenhauer, $A$ necessidade metafísica do homem, e sua relação com alguns autores que também viram a origem da filosofia no páthos (experiência, paixão, tonalidade afetiva) da admiração. O intuito do texto é mostrar como certos argumentos do filósofo alemão podem ser remetidos a pensadores antigos, e isso não apenas pelo fato de Schopenhauer citar nominalmente Platão e Aristóteles, mas pela própria

${ }_{1}$ Professor Adjunto do Departamento de Teoria e Fundamentos da Educação e do Programa de Pós-Graduação em Filosofia da Universidade Federal do Paraná (UFPR), Curitiba, PR - Brasil. (D) https://orcid.org/0000-0001-6752-259X. E-mail: reusengler@gmail.com

http://dx.doi.org/10.1590/0101-3173.2019.v42n3.02.p9 
forma como ele retoma e destrinça a questão em apreço. Noutras palavras, seu percurso argumentativo persegue consequências dialéticas que já orbitavam o horizonte grego, quando se tratava de pensar o nascimento da filosofia, e constitui, assim, uma retomada criativa da topica admirationis. ${ }^{2}$ Baseando-se em uma produtiva ideia de Pierre Hadot, para quem a filosofia antiga sói reaparecer, na modernidade, através daquilo que a retórica e a dialética clássicas chamavam de tópoi (HADOT, 2012), o artigo elenca cinco loci communes visíveis em Schopenhauer.

O primeiro deles mostra que a filosofia é uma disposição subjetiva que implica certo desconforto (Übel) existencial, o qual se traduzia nos antigos através da experiência da aporia. O segundo acrescenta que essa disposição não apenas origina a filosofia, mas também a coordena em suas diversas etapas, como subentendido no conceito de $\operatorname{arché~(princípio,~origem,~governo).~}$ $\mathrm{O}$ terceiro apresenta o conhecimento filosófico como um saber de índole sumamente universal (kathólou) e, portanto, inútil do ponto de vista prático. $\mathrm{O}$ quarto tópos entende a filosofia como um tipo de reflexão que se aplica primordialmente ao cotidiano e àquilo que nos é mais habitual. E o quinto, por fim, cuja mais alta expressão foi o estoicismo, consiste em afirmar que a admiração seria impensável em um mundo procedente de uma substância absoluta ou feito de eventos necessários.

Depois de discorrer sobre as principais consideraçôes de Schopenhauer (seção I) acerca da origem da metafísica/filosofia, expôe-se a ligação de seu pensamento com esses cinco tópoi (seção II) e defende-se, na conclusão, que sua contribuição à topica admirationis reside basicamente em dois pontos: na explicação da origem da filosofia através da metafísica da vontade, consequên-

\footnotetext{
${ }^{2}$ Topica admirationis designa o conjunto de lugares-comuns (tópoi ou loci communes) relativos à ideia de que a filosofia se origina na experiência de admiração. Por trás desse conceito, estende-se a longa tradição lógica e retórica da Antiguidade greco-romana. Em sentido lógico-dialético, o termo tópos foi adotado metaforicamente com base no contexto militar, onde significava o lugar a partir do qual certa ação se desenvolvia. Assim, passou a designar ao menos duas coisas: uma estratégia ou linha de argumentaçáo; um princípio ou elemento para a solução e/ou investigação de determinado problema. Embora Aristóteles não defina o termo na obra homônima, ele claramente o associa à dialética e à ideia de que, em vista do estudo dos lugares, seria possível argumentar sobre qualquer tema imaginável (Top. 100a18-24). Na Retórica, por sua vez, ele diz que o lugar equivale a um elemento (stoikheîon), porque ambos os conceitos são chaves cujo escopo abarca muitos entimemas (Rhet. 1403a1-19). Noutras palavras, os lugares são algo como argumentos semiprontos, os quais sempre surgem em determinadas discussôes; na política, por exemplo, a possibilidade é um lugar-comum, porque basicamente toda a discussão deve versar sobre algo que pode ou não acontecer (Rhet. 1391b27-28). A linguagem fática atribui à expressão lugar-comum um sentido similar. Para uma discussão desse conceito na Antiguidade, que investiga igualmente as contribuiçōes de Cícero, confira-se o excelente estudo de Rubinelli (2009).
} 
cia natural de seu sistema, e, sobretudo, na inflexão pessimista com que reinterpreta o primeiro locus.

\section{A ADMIRAÇÁO COMO ORIGEM DA METAFíSICA}

Nos complementos a sua obra principal, capítulo 17, Schopenhauer discute a origem da metafísica a partir da admiração e retoma assim, com adendos e modificações, vários tópoi da filosofia antiga, especialmente de Platão e Aristóteles. O texto intitula-se $A$ necessidade metafísica do homem e propóe-se elucidar o que o filósofo escreveu na seção 15 do livro I, a saber, sua caracterização do conhecimento matemático. Todavia, a discussão basicamente nada diz da matemática e prolonga-se em digressóes sobre a origem da metafísica e da religião, suas respectivas similaridades e diferenças. ${ }^{3}$ No fundo, ela se remete ao contexto da seção 15 , à medida que esclarece a natureza do conhecimento metafísico do próprio sistema de Schopenhauer - um conhecimento que ultrapassa a aparência e, mesmo assim, permanece imanente -, o qual possui diferenças substanciais em relação à natureza da matemática. É no interior dessa discussão que Schopenhauer encontra a oportunidade de aclarar a origem do impulso que faz com que o homem, tentando alçar-se para além da sensibilidade, acaba por dar à luz a metafísica.

Para Schopenhauer, a metafísica se origina no homem em virtude de uma gama de fatores. Primeiramente, ela nasce devido a uma contraposição natural e inevitável entre a vontade e o intelecto. Erguendo-se a um de seus mais altos graus, a vontade desdobra-se em intelecto e contrapóe-se a si mesma, podendo entáo admirar-se com seu próprio existir e com o mundo a sua volta. Trata-se de algo perfeitamente natural, pois representa novo estágio da essência da natureza, que agora se objetiva em grau mais elevado e enseja a entrada da razão. Em função da razão e do pensamento, a vontade reencontra a si mesma no mundo a sua volta, fato esse que a leva a admirar-se com suas próprias obras e a indagar o que são. Desse desmembrar-se da vontade aflora o primeiro impulso metafísico do homem. Porquanto esteja ligado à razão, esse impulso só pode desenvolver-se no homem, o único ser que se assombra com o próprio existir. Nos animais, ainda impera o sossego do olhar de uma natureza una e idêntica, que ainda não refletiu nem se desdobrou sobre si mesma.

\footnotetext{
3 Para uma discussão crítica da concepção schopenhaueriana de evidência matemática intuitiva, especialmente nas demonstraçôes, confira-se Rostand (1953).
} 
Eles permanecem confortavelmente atados ao tronco da natureza e partilham assim de sua inconsciente onisciência:

Dentre todos os seres, apenas o homem se surpreende com a sua própria existência. Todos os outros consideram essa uma condição que se compreende por si mesma, e que náo os assombra. A sabedoria da natureza fala no olhar pacífico dos animais, pois neles a vontade e o intelecto não estáo separados de modo amplo o suficiente para que cada um deles seja capa de se surpreender com o outro quando se encontram novamente. Portanto, neles o fenômeno inteiro permanece firmemente atado no tronco da natureza do qual brotou, e participa da inconsciente onisciência da grande mãe. (SCHOPENHAUER, 2014, p. 249).

Em segundo lugar, Schopenhauer discute um tipo de admiração que já envolve juízo mais elaborado sobre si mesmo e sobre o mundo, e que não é de todo prazerosa. Trata-se de uma estupefação (Verwunderung) que aumenta a admiração mencionada e que nasce a partir da consciência de nossa finitude - isto é, a consciência da morte - e da constataçẫo da inutilidade de todos os nossos esforços, a qual se impóe ao homem em maior ou menor medida. Tal estupefação - que se pode chamar de valorativa ou moral, haja vista se refira ao valor da existência - varia conforme o nível de consciência que o homem adquire desses dois fatores. É nesse sentido que o homem é um animal metafísico. Por um tempo, ele goza da inconsciência natural dos animais e toma seu ser como algo compreensível em si mesmo; não demora muito, porém, para que a primeira reflexão faça sua entrada e ele se sinta estupefato. Verdadeira mãe da metafísica, essa estupefação já teria sido reconhecida por Aristóteles, cuja sentença sobre a admiração, do livro Alfa da Metafísica (982b11-24),

E seu assombro se torna ainda maior quando se coloca com consciência pela primeira vez face a face com a morte, e além da finitude de toda a existência, se lhe impóe em maior ou menor grau a inutilidade de todos os nossos esforços. Com essa reflexão surge também uma necessidade metafísica, que só é peculiar ao homem: ele é, portanto, um animal metaphysicum. (SCHOPENHAUER, 2014, p. 249-250).

A ligação da morte com o surgimento da filosofia é um tema a que Schopenhauer retorna nos complementos ao livro IV, capítulo 41, quando discute a morte e sua relação com a indestrutibilidade de nosso ser-em-si. Nessa ocasião, ele lembra a emblemática afirmação de Sócrates, no Fédon (81a1), conforme a qual a preocupação com a morte (melétē tou tanáthou) seria a ver- 
dadeira fonte da filosofia. Dificilmente pôr-se-ia alguém a filosofar, segundo ele, se nosso ser fosse infinito e imortal. No reino animal, não há semelhante preocupação, sendo que cada indivíduo desfruta imediatamente da imortalidade da espécie. Nos homens, ao contrário, a razão faz surgir inevitavelmente a assustadora consciência da morte. Como compensação para esse mal-estar (Übel), ela os ajuda a criar toda a sorte de pontos de vista metafísicos, os quais lhes servem de consolo para sua finitude. Schopenhauer deriva desse consolo, outra vez, a fundação dos sistemas metafísicos e das religióes, ambos os quais são um antídoto para a consciência da morte:

$\mathrm{O}$ animal vive sem nenhum conhecimento apropriado sobre a morte, e, por isso, o indivíduo animal imediatamente goza da absoluta imperecibilidade e da imortalidade da espécie, uma vez que é consciente de si mesmo apenas como interminável. Junto com a faculdade da razão, apareceu necessariamente para o homem a certeza terrível da morte. Mas, assim como em toda a natureza um remédio é dado para todos os males, ou pelo menos uma compensaçáa, de modo correlato, a mesma reflexão que introduziu o conhecimento da morte nos auxilia na obtençáo das concepçóes metafísicas. Tais pontos de vista nos consolam a respeito da morte, das quais o animal não tem necessidade, e sequer é capaz. Todas as religióes e sistemas filosóficos são dirigidos principalmente para obter esse efeito, e são, principalmente, portanto, antídotos para a certeza da morte engendrados pela razão reflexiva a partir de seus próprios recursos. (SCHOPENHAUER, 2014b, p. 151). ${ }^{4}$

Além da percepção da nossa finitude, há a percepção do mal moral de que é feito o mundo. Schopenhauer repisa esse fato aqui e ali. A admiração filosófica se origina a partir de nosso lançar de olhos sobre o mal do mundo e o desconforto que ele provoca, os quais dão a entender que este mundo é algo que definitivamente não deveria existir, mesmo em uma situação em que o bem pudesse fazer frente ao mal. $\mathrm{O}$ mal, o desconforto e a morte caracterizam e aumentam o espanto filosófico. Portanto, esse espanto não é produzido apenas pelo fato de que o mundo existe (vorhanden ist), mas sobretudo pelo fato de que ele é assim miserável (trübselig). Esse é ponto fulcral da metafísica, que póe a humanidade em contínuo desassossego:

Assim, como nós já dissemos acima, o mal, a dor e a morte caracterizam e intensificam o espanto filosófico. $\mathrm{O}$ punctum pruriens da metafísica não está apenas em que o mundo exista ainda, mas que ele seja tão miserável

\footnotetext{
${ }^{4}$ Sobre a morte em Schopenhauer, confira-se o excelente artigo de Schöndorf (2009), que apresenta as principais reflexôes do filósofo sobre o tema.
} 
e melancólico. E este é o problema que desperta na humanidade uma agitação que não pode ser acalmada pelo ceticismo ou pelo criticismo. (SCHOPENHAUER, 2014, p. 265).

É importante notar que a autêntica disposição filosófica (Anlage) consiste em sentir-se estupefato em relação àquilo que nos é habitual e cotidiano, uma vez que, destarte, o universal da aparência é transformado em problema filosófico. Ou seja, de uma forma ou de outra, a admiraçáo deve tanger o problema da Totalidade. Tal disposição se diferencia da admiração curiosa que os cientistas devotam à natureza, pois esta tem como objeto apenas fenômenos raros e precisos, cuja decifração se dá à medida que são reconduzidos a um corpo de conhecimento prévio. Essa diferenciação se conecta com o já aludido desdobrar-se da vontade em intelecto. Quanto mais medíocre uma pessoa é, do ponto de vista intelectual, tanto menos enigmática se lhe afigura a existência; tudo o que vê lhe parece compreensível por si mesmo. Isso ocorre porque seu intelecto não se alçou ao nível das perguntas filosóficas e serve ainda, como nos seres inferiores, como simples meio para os motivos da vontade. Estando mais próxima de uma objetivação inferior do ser-em-si, ela náo consegue abstrair-se da totalidade das coisas, contrapor-se a ela e abarcar o mundo de forma puramente objetiva. Sempre que pensa sobre si e sobre o mundo, usa sua razão de forma instrumental, como meio para satisfazer seus instintos de sobrevivência:

Quanto menos expressiva for uma pessoa do ponto de vista intelectual, menos enigmática a existência lhe parecerá. Pelo contrário, lhe parecerá natural que tudo seja o que é e como é, e isto resulta do fato de que o seu intelecto ainda não superou o seu destino originário como serviçal da vontade, como mediador entre esta e os motivos, estando, portanto, firmemente atado ao mundo e à natureza, como uma parte integrante deles. (SCHOPENHAUER, 2014, p. 250).

No entanto, esta não é a única razão. Por um lado, o surgimento da admiração filosófica se prende a um maior desenvolvimento da razão; por outro, seu mais forte impulso (stärkster Anstoß) provém da consideraçáo do sofrimento e da penúria da vida, como exposto. Esse espanto moral ou valorativo é inexistente não apenas nos animais e nos homens que pouco desenvolvem sua razão. Ele também desapareceria em dois outros casos: se a vida humana fosse infinita e isenta de dores, como dito na passagem acima citada do texto sobre a morte e a indestrutibilidade de nosso ser-em-si; ou se 
a essência do mundo fosse uma substância necessária. Esta é a principal razão por que Schopenhauer acredita que o panteísmo esteja errado. Fosse o mundo uma substância absoluta, cuja possibilidade equivalesse à sua realidade, tanto seu não-ser quanto seu ser-outro seriam impensáveis; ele seria desde sempre o mesmo. Nosso próprio ser perderia seu caráter enigmático e se tornaria tâo correntio e compreensível quanto o fato de que $2+2=4$, uma vez que teria de ser concebido como acidente ou atributo de tal substância. Embora Schopenhauer evoque o panteísmo de Spinoza ${ }^{5}$, náo seria talvez precipitação ver aqui outra crítica a Hegel, em cujo sistema o real e o racional se equiparam em uma unidade inabalável, sugerindo a tese de que a existência do mundo é absolutamente necessária (HEGEL, 1993, p. 24). ${ }^{6}$ Em todo caso, fosse o mundo tal, não conseguiríamos ao menos questioná-lo filosoficamente, tamanha seria a identidade entre nosso ser e o seu. A existência do impulso filosófico prova que as coisas não são assim.

Em outras palavras, a partir de uma disposição humana, Schopenhauer refuta duas teses metafísicas: o otimismo das religiôes reveladas e a unidade imaculada do panteísmo. À proporção que a consciência humana se eleva, segundo ele, as cabeças mais aptas desenvolvem o afeto próprio da filosofia outrora mencionado por Platão, o thaumázein (aqui ele cita a famosa tese do Teeteto). Esse espanto se fundamenta, por conseguinte, no fato de que o náoser do mundo é tão possível quanto seu ser. E ele ocupa ininterruptamente os homens mais nobres em todos os países e épocas, tomando-os por inteiro e não lhes deixando nenhum descanso:

\footnotetext{
${ }^{5}$ Em outro texto, Schopenhauer censura os panteístas porque, se eles tivessem razão, a moral seria impossível: "Os panteístas não podem ter nenhum moral pensada seriamente - pois para eles tudo é divino." (SCHOPENHAUER, 2003, p. 120). Essas consideraçôes parecem nascer da necessidade de diferenciar seu sistema do dogmatismo transcendente de Spinoza e, ademais, da necessidade de tomar posição em relação à Querela do Panteísmo que se acendeu na Alemanha, no final do século XVIII.

${ }^{6} \mathrm{~A}$ influência de Spinoza sobre Hegel é de há muito conhecida; o filósofo alemão teria dito que era impossível ser filósofo sem antes ter sido spinozista. Como sabido, o significado do sistema de Spinoza foi ardentemente discutido, na Alemanha do final do XVIII, em virtude do Pantheismusstreit, isto é, a querela entre Mendelssohn e Jacobi sobre se Lessing teria sido ou não um adepto de Spinoza. Sobre isso, confira-se o clássico comentário de Beiser (1987). Embora Hegel não seja propriamente panteísta, porque acredita que Deus, conquanto imanente, é mais do que a mera soma das partes do mundo, seu panenteísmo compartilha com Spinoza a ideia de que a realidade do mundo é divina. Em outras palavras, para ele, a realidade histórica é um processo teleológico e racional que encontra plena realização no Saber Absoluto (PLANT, 1997, p. 31, 56; HYPOLLITE, 1995, p. 18). Esta é a tese a que Schopenhauer se opóe no escrito aqui em apreço, porque, fosse ela verdadeira, não haveria lugar para a admiraçáo. No que se refere a Hegel, ele censura o fato de que, em sua filosofia da história, este toma a aparência pela essência do mundo, adotando assim "um realismo raso e grosseiro" (SCHOPENHAUER, 2014c, p. 121).
} 
De fato, a agitação que mantém em movimento inesgotável o relógio da metafísica é o conhecimento claro de que a não existência neste mundo é tão possível quanto o é sua existência. Portanto, a visão de Spinoza, de que o mundo apresenta um modo absolutamente necessário da existência, em outras palavras, como algo que positivamente e em todos os sentidos deveria e deve ser, é falsa. (SCHOPENHAUER, 2014, p. 265).

Essa ininterrupta atuação do impulso metafísico é o que permite a Schopenhauer dizer que se trata de uma necessidade (Bedürfnis). Note-se que, em alemão, duas palavras há para nomear a necessidade. A palavra usada como título por Schopenhauer denota um gênero de necessidade que exige satisfação e que pressupóe a ideia de carência ou precisáo. Para a necessidade como antônimo de contingência, o alemão possui a palavra Notwendigkeit. Entretanto, pelo exposto, pode-se observar que o segundo sentido não está ausente em Schopenhauer, haja vista o nascimento da metafísica se ligue necessariamente ao aflorar da consciência: "Junto com a faculdade da razão, apareceu necessariamente (notwendig) para o homem a certeza terrível da morte." (SCHOPENHAUER, 2014b, p. 151). Mas é o sentido de carência que ele tem em mente, quando afirma, na sequência, que a metafísica e a religião são formas de satisfazer essa necessidade humana: "Vamos considerar agora as diferentes formas de satisfazer (Befriedigung) esta forte necessidade metafísica." (SCHOPENHAUER, 2014, p. 254). Aqui se iniciam suas consideraçóes sobre as similaridades e, principalmente, as diferenças entre a metafísica e a religião, as quais, por uma questão de afinidade temática, não serão discutidas neste artigo.

A partir da necessidade de satisfação do impulso metafísico, Schopenhauer deriva uma crítica muito oportuna ao naturalismo e ao materialismo. Para ele, tal impulso nos leva inexoravelmente a um conhecimento além das sensaçóes, porque não pode ser saciado pela mera explicação causal dos fenômenos. Um conhecimento desse feitio jamais daria conta, por exemplo, do problema da morte. A explicação exclusivamente física, a qual caracteriza as ciências da natureza, é incompleta por dois motivos. Primeiro, porque ela sempre pode ser levada ao infinito, isto é, ao um suposto início da série de causas e efeitos que permanece inescrutável; e, como esse início não pode ser elucidado mediante outras causas empíricas, pois náo se apresenta na sensibilidade, ela possui um componente residual inexplicável, que a torna um conhecimento condicionado ou relativo. Segundo, porque a física não explica satisfatoriamente as qualidades e forças naturais que atuam sobre as 
coisas. A dureza, o peso, a elasticidade, as forças químicas, a eletricidade e coisas similares não podem ser clarificadas por meios meramente físicos e, assim, um objeto táo prosaico quanto um pedaço de argila possui qualidades não dilucidadas em sua composição e nunca é cabalmente decifrado. Tais são as duas carências incontornáveis do conhecimento restrito à empiria (SCHOPENHAUER, 2014, p. 266ss).

No entanto, isso não quer dizer que Schopenhauer seja contra o desenvolvimento da física. Esse desenvolvimento é desejável porque, além de derrubar as metafísicas antigas, torna cada vez mais clara e premente a necessidade de ultrapassar o âmbito físico. Ou seja, ao invés de superar a metafísica, o progresso da física revela sua necessidade (SCHOPENHAUER, 2014, p. 272-273). Isso é particularmente evidente para o homem que, apreendendo o mundo de forma objetiva, busca compreender sua existência. Seu desconforto e estupefação são deveras urgentes e não encontram sossego enquanto não formam, de maneira cada vez mais sistemática, uma concepção da totalidade das coisas. Nesse ponto, Schopenhauer parece deambular em torno de um pensamento de Kant, o qual também acreditava que a razão humana, em sua ânsia de atingir a suprema unidade teórica, tendia forçosamente à superação do empírico e à transgressão dos limites da razão. Sua diferença entre pensar e conhecer um objeto, que desempenha papel insubstituível na refutação do argumento teológico, por exemplo, é expressão sintomática disso (KANT, 1967, p. 567). ${ }^{7}$ Porém, ao passo que Kant denuncia essa ânsia e mostra as antinomias a que conduz a razão humana, Schopenhauer vê nela a expressão genuína do conhecimento filosófico, o qual é superior ao conhecimento físico e sempre almeja ultrapassá-lo, como afirma em companhia de Aristóteles (SCHOPENHAUER, 2014, p. 269). Tendo consciência de que tal opinião está em conflito com a posição kantiana, ele define sua filosofia como uma metafísica imanente, isto é, como um conhecimento que consegue

\footnotetext{
7 Schopenhauer (1997, p. 119) admite que sua filosofia fique inteiramente sob influência da filosofia kantiana e que pressuponha necessariamente uma parte dela; em certo sentido, seu sistema é "apenas o pensar a filosofia de Kant até o fim." (SCHOPENHAUER, 2003, p. 118-119). Todavia, a divergência entre ambos, afora questôes mais pontuais, como a questão das categorias do entendimento, está precisamente no fato de que Schopenhauer reúne duas posiçóes que Kant tornara inconciliáveis: o dogmatismo e o criticismo. Ou seja, os princípios doutrinais de seu sistema são dogmáticos, porém, em virtude da crítica da razão, permanecem imanentes (SCHOPENHAUER, 2003, p. 118). Essa diferença se reflete no fato de que Schopenhauer julga possível decifrar o que seja a coisa-em-si e, por conseguinte, na ideia de que a ânsia humana de ultrapassar os limites da razáo via metafísica, como discutido acima, é expressão do genuíno conhecimento filosófico.
} 
dizer o que está por detrás dos fenômenos sem que, para tanto, precise alijar-se da experiência:

A metafísica, portanto, permanece imanente, pois nunca se subtrai da experiência, mas, pelo contrário, continua a ser uma simples interpretaçáo e explicação da mesa, pois nunca se fala da coisa em si a não ser em sua relação com o fenômeno. Este, pelo menos, é o sentido em que eu tentei resolver o problema da metafísica, levando em consideração os limites do conhecimento humano que forma demonstrados por Kant. (SCHOPENHAUER, 2014, p. 279).

Este último assunto, contudo, não tem imediata importância para a presente discussão. ${ }^{8}$

\section{A TOPICA ADMIRATIONIS}

Ao fazer esses comentários sobre a admiração, Schopenhauer transita por alguns lugares-comuns (tópoi) com que a tradição filosófica, desde os gregos, pensou a origem da filosofia. Cumpre enfatizar que ele não o faz com vistas a interpretar o legado antigo. A despeito de citar Platão e Aristóteles, Schopenhauer não está interessado em explicar objetivamente tais autores como prova, por exemplo, o fato de não os diferenciar entre si -, mas antes em ilustrar como seu pensamento está de acordo com os dois maiores vultos do classicismo grego. Assim, utiliza uma variante do argumento de autoridade (magister dixit), um modo de raciocínio costumeiro em sua obra. ${ }^{9}$ Porém, não se trata de um simples emprego desse argumento, como talvez no caso dos medievais; trata-se de algo provavelmente associado a uma concepção sui generis de verdade.

\footnotetext{
${ }^{8}$ Confira-se sobre isso o artigo de Morgenstern (1987). O autor ressalta três diferentes concepções de metafísica em Schopenhauer, as quais se remetem a diferentes tradiçôes: a metafísica como reformulação conceitual (Abbildung) do mundo empírico ligar-se-ia a uma concepção simultaneamente realista e materialista de mundo; a metafísica como decifraçáo (Entzifferung) do mundo fenomênico, por sua vez, pressuporia uma intepretação hermenêutica similar à busca da teologia pelo sentido do mundo; e, por fim, a metafísica imanente teria raízes na filosofia transcendental (MORGENSTERN, 1987, p. 602).

9 Isso se reflete, por exemplo, no fato de que Schopenhauer vê nos demais filósofos a confirmação parcial de seu sistema, como se eles tivessem se acercado da solução do enigma do mundo, embora não a divisassem de todo. Ele parece seguir o método de conciliação (eugnōmosýnē) dos estoicos, o que se reflete, para citar alguns exemplos, em seus comentários a Empédocles, Pitágoras, Platão e aos próprios estoicos (SCHOPENHAUER, 2003, p. 25, 28, 42).
} 
Com efeito, Schopenhauer compreende a veracidade de sua filosofia em termos musicais ou harmônicos: o motivo por que seu sistema oferece a melhor explicação do mundo da aparência reside, pois, na confirmação reiterada de seu pensamento fulcral em confronto com os mais diferentes fenômenos (SCHOPENHAUER, 2014, p. 281). Seu sistema disponibiliza o alfabeto que transforma as letras do mundo em palavras plenas de sentido, e sua confirmação se dá através de um tipo de consonância. ${ }^{10}$ Os sistemas de Leibniz, de Wolff e de Spinoza não são falsos porque partem de uma base abstrata e não intuitiva, mas porque entram em conflito com certos aspectos do mundo: o otimismo de Leibniz é incompatível com a flagrante miséria da existência, ao passo que Spinoza se deixa refutar por nosso espanto ante o caráter arbitrário do ser. Em contrapartida, todos os fenômenos do mundo da aparência soam no mesmo timbre, quando se lhes aplica a chave schopenhaueriana. ${ }^{11}$ As citaçôes dos antigos, que Schopenhauer considera nossos mestres no terreno da metafísica (SCHOPENHAUER, 2014, p. 284), demonstram a harmonia de uma série de pensamentos que não sofre de nenhum acorde dissonante.

Dito isso, convém agora mostrar quais são os tópicos que Schopenhauer retoma da antiga doutrina da admiração. Conquanto evoque apenas Platão e Aristóteles, seus argumentos percorrem uma órbita maior, a qual também tangencia reflexóes do estoicismo. Isso não ocorre, de novo, em virtude de uma interpretação objetiva dessas antigas ideias; ocorre porque sua linha de raciocínio tem de tocar inevitavelmente certos temas, à medida que parte do horizonte já aberto pela filosofia grega. Por mais original que um filósofo seja, se ele defender o eterno fluir das coisas, seus argumentos hão de encontrar, mais cedo ou mais tarde, alguma intuição de Heráclito. $\mathrm{O}$ mesmo se pode dizer acerca do problema do nascimento da filosofia e de outros tópoi, como a ideia

\footnotetext{
10 "Assim, o meu ensino nos permite perceber acordo e consistência na confusão dos contrastantes fenômenos deste mundo, e resolve as inúmeras contradiçóes que, vistas de todos os outros pontos de vista, são apresentadas por ele." (SCHOPENHAUER, 2014, p. 282).

11 "Eu considero como um grande mérito da minha filosofia que todas as suas verdades foram encontradas independentemente umas das outras, através de uma consideração do mundo real, apesar de eu não ter me preocupado inicialmente com sua unidade e concordância, ainda que sempre se mostrassem por si mesmas depois." (SCHOPENHAUER, 2014, p. 283). Em outra ocasiāo, ao falar do próprio sistema, as mesmas ideias reaparecem: "Por isso, pude também sempre ficar despreocupado quanto à harmonia de meus princípios, até mesmo quando alguns deles me pareciam incompatíveis, como aconteceu algumas vezes num certo período de tempo. Pois encontrou-se depois a concordância por si mesma, na medida em que os princípios apareceram juntos e completos. Porque a concordância não é para mim outra coisa senão a concordância da realidade consigo mesma, algo que nunca pode faltar." (SCHOPENHAUER, 2003, p. 119).
} 
de que a natureza não dá saltos ou de que devemos conhecer a nós mesmos. ${ }^{12}$ É assim que Hadot compreende a transmissão da filosofia antiga (HADOT, 2012, p. 36ss), ou seja, como a permanência e a retomada de argumentos já descobertos na Antiguidade.

O primeiro lugar-comum presente no texto, cuja fonte é o Teeteto de Platão, consiste em pensar o início da filosofia a partir de uma disposiçáo anímica. No Teeteto, Platão afirma que o filósofo é acometido, mais do que os outros homens (mála), pelo páthos (experiência, paixão, disposição) do maravilhamento, e descreve com esse conceito retórico uma experiência que paira entre a irracionalidade das emoçôes e o domínio da razão: ${ }^{13}$

Teeteto: Mas pelos deuses, Sócrates, admiro-me além do natural que as coisas possam ser assim, e às vezes, quando verdadeiramente volto os olhos para elas, chego a ter vertigens.

Sócrates: Estou vendo, amigo, que Teodoro não ajuizou erradamente a tua natureza. Sobretudo é próprio do filósofo, pois, esta experiência, o admirar-se. Outro não é o princípio da filosofia senáo este. Ao que parece, não foi mau genealogista quem disse ter Îris nascido de Taumante. Porém já compreendes a relação entre tudo isto e a proposição que atribuímos a Protágoras? Ou náo? (Tht. 155c8-d7, tradução nossa).

O páthos configura experiência simultaneamente intelectual e emotiva que, apesar de acontecer à revelia do agente, pode ser minimamente dirigida pela razão. Ele não se confunde com o apetite (epithymía), normalmente descrito com cores pejorativas, e denota antes uma predisposição do sujeito que pode tornar-se boa ou má, dependendo de seu emprego. ${ }^{14}$ Schopenhauer, por sua vez, compreende a admiraçáo como impulso (Anstoß) e como disposição de espírito (Anlage), termo esse que, em alemão, poderia ser expresso pela pa-

\footnotetext{
${ }^{12}$ Para a aplicação da ideia de Hadot ao tópos da inspiração poética, no caso específico de Nietzsche, cf. Engler (2017).

${ }^{13}$ Para uma discussão do conceito de admiração na Antiguidade, confiram-se os seguintes estudos: Nightingale (2009); Reale (1993); Berti (2010); Pieper (2014); Albert (1991); Engler (2011).

${ }^{14} \mathrm{Na}$ República, o termo é usado quando Platão fala dos cães de guarda. Ele significa então uma disposição que faz com que tais cães acolham bem os conhecidos e desconfiem dos desconhecidos (Resp. 376b). No Sofista, ele é utilizado para descrever a situação de ignorância ou não purificação de um indivíduo (Sph. 228e4). E, na alegoria da caverna, por sua vez, ele denota a condição dos cavernícolas (Resp. 514a1-2), provando que se trata de uma experiência geral, não apenas de uma emoçấo. Sobre a ligação entre o páthos e a ignorância, confira-se Engler (2018). Para a discussão de outros empregos do termo, confira-se Pradeau (2008).
} 
lavra Gemütsanlage. Sem discutir se sua origem está na razão ou nas emoçóes do sujeito, ele aceita que se trata de algo subjetivo.

Ademais, em Platão, a admiração nasce junto de outras experiências nem sempre prazerosas, embora fundamentais para o florescer da filosofia. Tal é o caso da aporia, das dores do parto (Tht. 149a9), do deslumbramento (Resp. 5151c4-6), do choque elétrico (Men. 80a4-5), do sentimento de vertigem e de loucura (Smp. 217e6218b5) com que ele retrata o início psíquico da filosofia, alguns dos quais são explorados na alegoria da caverna. Sobre a aporia (aporeîn), verdadeiro aguilhão do filósofo, Aristóteles concorda com seu mestre, acrescentando que o filósofo busca o fim desse sentimento através do conhecimento universal das causas dos fenômenos:

Por outro lado, a posse dessa ciência deve nos levar ao estado oposto àquele que nos encontrávamos no início das pesquisas. Como dissemos, todos começam por admirar-se de que as coisas sejam tais como são, como, por exemplo, diante das marionetes que se movem por si nas representaçóes, ou diante das revoluçóes do sol e da incomensurabilidade da diagonal com o lado de um quadrado. Com efeito, a todos os que ainda náo conhecem a razão disso, causa admiração que entre uma e outro não exista uma unidade mínima de medida comum. Todavia é preciso chegar ao estado oposto e também melhor, conforme afirma o provérbio. E assim acontece, efetivamente, para ficar nos exemplos dados, uma vez que se tenha conhecido a causa: nada provocaria mais admiração num geômetra do que se a diagonal fosse comensurável com o lado. Fica estabelecido, portanto, qual é a natureza da ciência buscada, e qual é o fim que a nossa pesquisa e toda a nossa investigação devem alcançar. (Metaph. 982b11-24).

Em Schopenhauer, parte desses pensamentos retorna, quando ele assevera que o sentimento filosófico é uma estupefação (Verwunderung) oriunda da consideração dos males do mundo, do mal-estar geral da vida, da consciência da morte e da inutilidade de nossos esforços. Acicatado por tal sentimento é que o filósofo se motiva a filosofar e a encontrar um consolo em consideraçôes que ultrapassam o mundo empírico. Isso quer dizer que, à semelhança do estado aporético, a necessidade metafísica é desfraldada por uma experiência subjetiva de desassossego. Um Esteves sem metafísica, que não se interroga sobre o mundo e o toma por algo compreensível, jamais engendraria um sistema metafísico ou religioso; este é o empreendimento do indivíduo para quem "a metafísica é uma consequência de estar maldisposto." (PESSOA, 1980, p. 260). Na reinterpretação desse antigo tópos, como defendido na conclusão, está a contribuição original de Schopenhauer à topica admirationis. 
Dos dois clássicos gregos também procede a ideia de que a admiração filosófica não apenas origina, senão governa a aventura filosófica em todas as suas etapas. Este é o segundo tópos. Embora com sentidos diferentes, tanto Platão quanto Aristóteles chamam o thaumázein de arché, palavra que significa não somente "começo", como também "governo" ou "regência". Foi Heidegger quem recordou os helenistas desse indispensável pormenor (HEIDEGGER, 1963, p. 38-40). Ao empregar tal vocábulo, os antigos afirmam que a filosofia é originada pela admiração e dirigida por ela em seu curso. Na Metafísica, Aristóteles descreve como o admirar-se do filósofo começa com as dúvidas mais próximas e ingênuas e vai-se estendendo até as mais distantes e abstratas; em cada um desses casos, é sua tentativa de fugir da ignorância, inerente à disposição taumática, que motiva e coordena suas investigaçóes (Metaph. 982b13-17).

Por sua vez, a partir do caráter ascensional de sua filosofia - que se reflete na teoria da reminiscência, na catarse, na scala amoris e na alegoria da caverna -, Platão demonstra como a admiração não é um evento primordial que ocorre apenas uma vez, no princípio da filosofia, senão um fenômeno reincidente que póe a filosofia em constante marcha. ${ }^{15} \mathrm{O}$ filósofo deve reiniciar continuamente sua investigação e acostumar-se com diferentes graus de verdade e realidade, os quais lhe oferecem respostas graduais que são superadas em seguida (HEIDEGGER, 1978). Isso fica claro nos eventos acima citados, sobretudo na anábase do cavernícola: em cada um dos estágios a que ele chega - na visão das sombras dos objetos, dos seus reflexos na água etc. - ele se interroga e admira, passando então para o próximo nível (Resp. 516a5-b7). Essa ideia ressurge, em Schopenhauer, com visos menos prazenteiros. Para ele, a admiração importuna a humanidade mais nobre sem interrupção e não lhe deixa outra escolha senão a criação de um sistema metafísico ou religioso que a asserene. Ou seja, em cada reflexão do filósofo vige a mesma percepção dos males do mundo que faz surgir a filosofia; em um pensador que leva a sério as diversas manifestaçóes da essência do mundo, ela não é esquecida ou deixada para trás, mas o impulsiona constantemente a interpretar os fenômenos e ir além deles, em busca de uma explicação. ${ }^{16}$

\footnotetext{
${ }^{15}$ Cf. Engler (2011, cap. III).

${ }^{16}$ A necessidade com que a filosofia surge inevitavelmente no homem não parece ser um tópos antigo, mas sim moderno. Nas reflexôes de Aristóteles, não é possível estabelecer com segurança que a filosofia deva surgir necessariamente depois de um tempo, embora seu pensamento possua inegáveis traços teleológicos. Na reflexão sobre as causas, por exemplo, ele postula a necessidade de descobrir quatro causas complementares, e sua doutrina parece surgir como que inexoravelmente depois das tentativas
} 
O terceiro lugar-comum que aparece no texto de Schopenhauer está no fato de que a filosofia é um saber inútil e universal, mas nem por isso menos nobre do que as demais ciências. Isso também está associado ao afeto filosófico. Aristóteles argumenta, por exemplo, que a reflexão desinteressada dos filósofos só pôde surgir depois que as artes haviam criado uma vida cômoda para o homem. As primeiras artes, como a arquitetura, orientavam-se táo-somente pela sobrevivência e pelo conforto, isto é, elas tinham um fim prático em vista e não podiam ser filosóficas. Apenas quando o homem se viu livre da rude necessidade é que a reflexão filosófica floresceu; agora, podia-se pensar sem outro fim, a não ser o conhecimento em si e por si mesmo. Por não se dirigir à ação, que é sempre particular (kath' hékaston), o saber da filosofia assumiu desde cedo sua índole universal (kathólou); historicamente, tornou-se privilégio das castas sacerdotais (Metaph. 981b20-25). Esse tópos é visível em Schopenhauer, quando ele afirma que a filosofia depende de um grau de objetivação da essência da natureza em que o intelecto deixa de ser apenas um meio da vontade e pode contemplar o mundo de forma objetiva. Logo, a filosofia é um saber universal e inútil às demandas mais prosaicas da vida. Por sua influência, o indivíduo desprende-se dos acicates da vontade e contempla o mundo objetivamente, isto é, contrapondo-se a ele em sua totalidade. A menção da totalidade é outra maneira de dizer que o saber filosófico é de cariz universal.

O quarto tópos consiste na ideia de que a admiração filosófica deve voltar-se para os fenômenos cotidianos e não apenas para os fenômenos raros e seletos das ciências naturais. Em Aristóteles, isso está claramente dito na Metafísica, quando ele assevera que a admiração versa primeiramente sobre aquelas coisas que nos são mais próximas, abarcando em seguida as mais distantes, como as manchas da lua e a geração/corrupção do universo (Metaph. 982b1317). Todavia, o Estagirita não desenvolve essa ideia tanto quanto seu mestre; é Platão que a apresenta de forma rica e colorida. A aplicação do thaumázein ao mundo cotidiano, em Platão, confirma-se pela extravagância (atopía) do filósofo pintada na alegoria da caverna e em outros Diálogos. Aos olhos do homem comum, o filósofo é alguém estranho e extravagante, porque não encara seu cotidiano como algo compreensível em si mesmo, porém o interroga e transforma via reflexão filosófica. ${ }^{17} \mathrm{Na}$ caverna, as coisas habituais

dos filósofos anteriores. Entretanto, isso não está claramente dito na questão da admiração. Esse tópos parece provir da filosofia de Kant, o qual, no prefácio à Crítica, afirma que a metafísica existiria mesmo depois de uma barbárie civilizacional, tamanha é a inevitabilidade com que o homem anseia por um conhecimento além do mundo fenomênico (KANT, 1967, p. 38).

${ }^{17}$ Sobre isso, confiram-se os seguintes estudos: Grimaldi (2006); Hadot (1999); Engler (2013). 
e cotidianas não são filosóficas e, por isso, o cavernícola que se liberta deve habituar-se (synétheia) a novos objetos e a uma nova realidade, à medida que ascende em direção às ideias. ${ }^{18}$ No Fedro, há quatro loucuras atribuíveis ao filósofo, as quais são, segundo Platão, uma modificação divina (theîa exallagê) de nossos hábitos (Phdr. 265a9); e a própria retórica filosófica ali perseguida diferencia-se da retórica usual por estender-se a assuntos cotidianos $(P h d r$. 261b-e). ${ }^{19}$

Dado que o filósofo seja acossado pelo páthos filosófico em proporção maior do que as pessoas comuns, pode-se sustentar que seu cotidiano não é imune a esse sentimento. As inúmeras situaçôes dialéticas encenadas nos Diálogos sugerem que temas à primeira vista banais, como a alimentação, a relação com os prazeres, a compreensão dos objetos materiais, entre outros, possuem inegável natureza filosófica, o que dá plena razão a Cícero, quando ressaltava que Sócrates trouxe a filosofia dos céus para a terra e começou a investigar o que se fazia de certo e errado nos lares e nas cidades (Tusc. Disput. $\mathrm{V}$, iv, 8-11). Tal parece ser a ideia de Schopenhauer, quando afirma que a admiração versa primordialmente sobre a nossa própria existência e sobre aquilo que nos é habitual. Surgida do desgarre do intelecto no seio da vontade, ela faz com que o filósofo observe como puro sujeito do conhecimento tudo o que as pessoas comuns ainda compreendem sob o prisma de um intelecto servil aos instintos da vontade de viver. Ao fim e ao cabo, naturalmente ele deve agir de forma peculiar, se comparado ao bom burguês.

O quinto tópos, por fim, assoma na refutação schopenhaueriana do panteísmo. Como explicado, Schopenhauer pensa que a admiração seria impossível, caso o mundo fosse uma substância necessária cuja possibilidade equivalesse à sua realidade. Este é o caso não apenas de Spinoza, mas também dos estoicos, os quais exerceram enorme influência sobre o pensador judeu. Com uma argumentação que remonta a pré-socráticos como Pitágoras e Demócrito, e deixa alguns vestígios em Aristóteles, o qual também propóe o filósofo atinja um estado oposto ao estado admirativo (Metaph. 983a11-23), os estoicos preconizam o fim da admiração (athaumastía), pois consideram absurdo que alguém se admire com qualquer evento deste mundo, quando tudo o que nele acontece possui uma causa necessária. Plutarco atribui a Pitágoras a máxima sapiencial do mèdèn thaumázein (não se admirar), que se transforma

\footnotetext{
${ }^{18}$ Acerca desse aspecto, Engler (2011, cap. IV) faz uma discussão pormenorizada.

${ }^{19}$ O estudo de Pieper (1962) sobre esse tema é ainda um dos melhores; no entanto, ele não percebe que as loucuras podem ser atribuídas ao filósofo. Quanto a isso, cf. Engler (2011, p. 100).
} 
no famoso Nil admirari de Horácio (SNELL, 1991, p. 39). E Marco Aurélio exemplifica esse ponto, quando diz: "Quão risível e estranho não é aquele que se admira por qualquer um dos eventos da vida!" (Medit. XII, 13) ${ }^{20}$ Ou seja, o verdadeiro sábio é aquele que conhece o curso do mundo e não possui razões para espantar-se com nada do que vê; ele é calmo e sereno como um pagáo horaciano, pois sabe que a única coisa que pode fazê-lo e conservá-lo feliz é a imperturbabilidade admirativa que lhe permite observar os astros, o sol e as estaçôes sem nenhum temor (formidine nulla) (Epist. VI, 1-5). ${ }^{21}$ Nesse sentido, Schopenhauer extrai corretamente as consequências práticas do panteísmo, ao salientar que tal filosofia exclui a admiração.

\section{Conclusáo}

Do que ficou dito pode-se concluir que a originalidade de Schopenhauer consiste, primeiramente, na interpretaçáo desses antigos tópoi à luz de sua metafísica da vontade. Essa originalidade não está diretamente calcada no tema da admiração, mas na própria filosofia de Schopenhauer. Noutras palavras, é claro que Schopenhauer deve ser original em relação aos antigos, já que nenhum deles desenvolveu uma metafísica da vontade e, a partir dela, interpretou o problema da origem da filosofia.

Entretanto, no interior da topica admirationis, sua originalidade reside na profunda reinterpretação do primeiro tópos, máxime no que toca ao desconforto que acompanha a origem da filosofia. As nuances detectáveis nos demais tópoi parecem depreender-se dessa inflexão pessimista. Essa contribuição é original, porque nenhum filósofo antes dele associou tão enérgica e claramente o irromper da filosofia à percepção do mal moral, da inutilidade de nossos esforços e da miséria da vida. Conquanto os antigos percebam o desassossego do filósofo, as dores e as vertigens de que sofre, eles ainda são sobremaneira otimistas e creem que o mundo foi criado e é governado por um princípio bom e divino, o que quer dizer, em última instância, que sua existên-

${ }^{20}$ Também Cícero parece ter adotado essa posição estoica. Nas Tusculanas, aparece outro locus classicus sobre a admiração, quando ele afirma que a sabedoria divina consiste em estudar profundamente as coisas humanas e não se admirar com nada que aconteça (nihil admirari cum acciderit, Tusc. III, xiv, 30).

${ }^{21}$ Nos Aforismos sobre sabedoria de vida, ao falar da velhice, Schopenhauer exalta como uma de suas benesses a convicção séria e imediata do caráter vão e da insignificância de todas as magnificências do mundo, o que tem por resultado o nil admirari horaciano, privilégio do homem idoso, a cujos olhos desapareceram todas as quimeras. Isso é típico, aliás, de todos aqueles que conseguiram anular a vontade (SCHOPENHAUER, 2002, p. 271). 
cia está plenamente justificada. É apenas em sua poesia, na épica e na tragédia, em específico, que ousam tomar o lado mais sombrio da existência como a verdadeira essência do mundo. ${ }^{22}$ Com seu ateísmo impiedoso, ao contrário, Schopenhauer ressalta que a filosofia não se origina apenas da consideração parmenídica de que o mundo existe, mas principalmente de que ele é assim tão melancólico (trübselig).

$\mathrm{Na}$ história posterior da filosofia, disposições incômodas como o tédio e a angústia serão magistralmente usadas por Heidegger como princípios da filosofia, o que poderia sugerir alguma similaridade com Schopenhauer (HEIDEGGER, 1983, 2006, \$29). ${ }^{23}$ Contudo, há diferenças incontornáveis: em Heidegger, as disposiçóes fundamentais não estabelecem nenhuma conexão com um juízo valorativo sobre a existência; antes, elas são como que condiçóes transcendentais para o devido desvelar-se dos fenômenos. ${ }^{24} \mathrm{Em}$ Schopenhauer, elas vão além dessa função e se transformam em sintomas

\begin{abstract}
${ }^{22}$ Eis a principal razão teológica por que Platão e Aristóteles se opõem à visão de mundo trágica. No caso de Platão, isso acontece em relação a teses específicas que aparecem na tragédia ática, como, por exemplo, a ideia de que a morte é um mal, de que os deuses são fontes de maldade, de que justiça e felicidade normalmente se excluem etc. Para Halliwell (2002, p. 108-110), o reconhecimento dessas teses faria de Platão o primeiro pensador do trágico. No caso de Aristóteles, isso ocorre pela exclusão dos deuses de sua poética ideal e pela identificação do caráter como real fonte de ação e, por conseguinte, do infortúnio trágico (hamartía), o que exclui qualquer perversidade divina ou do destino. Sobre isso, concordam os principais comentadores; Golden (1992, p. 81); Frede (1992, p. 212); Barnes (1999, p. 280); Schmitt (2012). Por fim, esse fato torna compreensível que Schopenhauer desenvolva uma filosofia do trágico em que a tragédia ática é louvada como ápice da arte poética, já que encerra em si a ideia de que o herói deve expiar a culpa pelo simples fato de existir (SCHOPENHAUER, 1991, \$51). Sobre isso, conferir: Szondi (2004); Machado (2006).

${ }^{23}$ Jacquette ressalta como ainda não se levantou adequadamente a questão sobre a similaridade entre Heidegger e Schopenhauer. Porque o primeiro criticou a ênfase biológica do segundo, suspendeu-se a pergunta sobre a relação entre os dois (JACQUETTE, 2005, p. 244-245). No entanto, de acordo com Jacquette, haveria vários pontos de contato: "In his existentialist ontology, Heidegger offers a remarkable transcription of Schopenhauer's philosophy into a twentieth-century idiom of Husserlian phenomenology and a concern with the ethics of technology." (JACQUETTE, 2005, p. 249). O próprio autor se esforça por apresentar entấo esses pontos: as noçôes de Sorge e Gelassenheit, as quais estariam relacionadas com a visão pessimista de Schopenhauer e a ideia de negação da vontade; a saída da vida inautêntica através da arte; a noçáo de Zuhandenheit como traduçấo da ideia de que nossas ações estão a serviço da vontade e, assim, concebemos os entes do mundo como coisas utilizáveis etc. Todavia, pela própria natureza do livro, sua apresentação é ainda geral e ignora semelhanças fundamentais, como o problema das disposiçóes (Stimmungen) e a consciência da morte, o Sein-zumTode de Heidegger. Ela serve, porém, como um primeiro mapeamento de possíveis questóes. Um estudo cabal deveria tratar, outrossim, do pensador que intermedeia a relação entre Schopenhauer e Heidegger: Friedrich Nietzsche. Pela aceitação de muitas ideias de Nietzsche, o qual criou sua filosofia, em grande parte, como uma reação ao pessimismo de Schopenhauer, Heidegger acaba por aceitar também, admita ele ou não, certas posições de Schopenhauer.
\end{abstract}

${ }^{24}$ Para uma breve discussão desse tema em Heidegger, cf. Engler (2010). 
oriundos da percepção do mal moral efetivo de que é feito o mundo, trazendo em seu bojo a constataçáo de que tanto a sua existência quanto a nossa, do ponto de vista da metafísica, não são absolutamente necessárias. Ou seja, a partir delas, elabora-se um juízo sobre a totalidade das coisas que implica profundas consequências éticas: a existência inteira é concebida como um episódio a perturbar inutilmente a paz bem-aventurada do Nada, e a única felicidade que parece restar, como se sabe, é a negação daquilo mesmo que compóe a essência do mundo: a vontade.

Aqui se revela o tom profundamente pessimista com que Schopenhauer reinterpreta o thaumázein. Se Kant admirava o céu estrelado e a lei moral dentro de si, aquele que se considerava seu mais fiel discípulo se espantava com o descalabro do mundo, e nisso acrescentava novos pensamentos a uma antiga tradição que encontrava na experiência de admiração o início da filosofia.

ENGLER, M. R. Schopenhauer and the topica admirationis: on the origin of philosophy. Trans/form/ação, Marília, v. 42, n. 3, p. 9-32, Jul./Set., 2019.

\begin{abstract}
In the text entitled On man's need of metaphysics, Schopenhauer makes important remarks on his immanent metaphysics and, trying to explain why men philosophize, joins a long tradition of thinkers who see in admiration (thaumázein) man's real metaphysical impulse (Anstoß). He reinterprets then the two most famous statements on this subject (those of Plato and Aristotle) in accordance with the tone of his philosophy. The origin of philosophy becomes the result of phenomena such as the separation between will and intellect and the perception that this world, which currently is, could just as well not be. The contemplation of the world's misfortunes and the consciousness of human finitude (death) is also dealt with. Metaphysical and religious systems emerge from these factors. This paper discusses in detail these ideas and analyzes their relationship with the ancient philosophers and the five tópoi. It also seeks to discover the originality of Schopenhauer's conception, which is based on the reinterpretation of the first topos.
\end{abstract}

KeYwords: Schopenhauer. Admiration. Metaphysics. Plato. Aristotle.

\title{
REFERÊNCIAS
}

ALBERT, K. Sul concetto di filosofia in Platone. Traduzzione italiana Paola Traverso. Milano: Vita e Pensiero, 1991. 
ARISTÓTELES. Ars Rhetorica. Organized by Sir. W. D. Ross. London: Oxford University Press, 1975.

. Topics. Translated by W. A. Pickard. In: BARNES, J. (ed.). The complete works of Aristotle. Princeton: Princeton University Press, 1991. V. 1.

- Metafísica. Traduçáo do grego de Giovanni Reale. Tradução do italiano de Marcelo Perine. São Paulo, Loyola, 1994. V. 2.

AURÉLIO, M. Meditações. Tradução de Jaime Bruna. São Paulo: Abril Cultural, 1980 (Os pensadores).

BARNES, J. (ed.) The Cambridge Companion to Aristotle. Cambridge: Cambridge University Press, 1999.

. Rhetoric and poetics. In: BARNES, J. (ed.). The Cambridge Companion to Aristotle. Cambridge: Cambridge University Press, 1999. p. 259-287.

BEISER, F. C. The fate of reason: german philosophy from Kant to Fichte. Massachusetts: Harvard University Press, 1987.

BERTI, E. No princípio era a maravilha: as grandes questóes da filosofia antiga. São Paulo: Loyola, 2010.

CICERO, M. T. Tusculan disputations. Translated by J. E. King. Loeb Classical Library. Cambridge; Massachusetts; London: Harvard University Press, 1996.

DIELS, H.; KRANZ, W. Die Fragmente der Vorsokratiker. Zürich: Weidmann, 1989.

ENGLER, M. R. Uma nova disposição fundamental: Heidegger e as contribuiçōes à filosofia. Revista PERI, Florianópolis, v. 2, n. 1, p. 65-80, 2010.

. Tò thaumázein: a experiência de maravilhamento e o princípio psíquico da filosofia em Platão. 244f. 2011. Dissertação (Mestrado em Filosofia)- Centro de Filosofia e Ciências Humanas, Universidade Federal de Santa Catarina, Florianópolis, 2011.

. O círculo retórico: Sócrates e caráter vertiginoso da filosofia. In: CARVALHO, M.; FIGUEIREDO, V. (org.). Encontro Nacional Anpof - Filosofia Antiga e Medieval. São Paulo: ANPOF, 2013. p. 357-369.

. Nietzsche e a inspiração poética: a oscilação entre os modelos de Platão e Aristóteles. Revista Dissertatio, v. 45, p. 113-130, 2017.

. A errância do filósofo platônico: dogmatismo, ignorância e aporia. Revista Guairacá, V. 34, n. 2, p. 85-109, 2018.

FREDE, D. Necessity, chance and "what happens for the most part" in Aristotle's Poetics. In: RORTY, A. (ed). Essays on Aristotle's poetics. Princeton:

Princeton University Press, 1992. p. 197-220.

GOLDEN, L. Aristotle on tragic and comic mimesis. Atlanta: Scholars Press, 1992.

GRIMALDI, N. Sócrates, o feiticeiro. São Paulo: Loyola, 2006. 
HADOT, P. O que é a filosofia antiga? São Paulo: Loyola, 1999.

. Elogio da filosofia antiga. São Paulo: Loyola, 2012.

HALLIWELL, S. The aesthetics of mimesis: ancient texts and modern problems. Princeton:

Princeton University Press, 2002.

HEGEL, G. W. F. Grundlinien der Philosophie des Rechts. Dritte Auflage. Frankfurt: Suhrkamp Taschenbuch, 1993.

HEIDEGGER, M. Sein und Zeit. Neuzehnte Auflage. Tübingen: Max Niemeyer, 2006. . Die grundbegriffe der Metaphysik: Welt, Endlichkeit, Eisamkeit. Frankfurt am Main: Vittorio Klostermann, 1983.

. Platons Lehre von der Warheit. In: HEIDDEGER, M. Wegmarken. 2. Auflage. Frankfurt am Main: Vittorio Klostermann, 1978.

. Was ist das - die Philosophie? Dritte Auflage. Tübingen: Günther Neske Pfullingen, 1963.

HORACE. Satires. Epistle: the art of poetry. Translated by H. Rushton Fairclough. Cambridge, MA: Harvard University Press, 1926.

HYPOLLITE, J. Introdução à filosofia da história de Hegel. Lisboa: Edições 70, 1995.

JACQUETTE, D. The philosophy of Schopenhauer. Chesham: Acumen, 2005.

KANT, I. Kritik der reinen Vernunft. Würzburg: Felix Meiner, 1967.

MACHADO, R. O nascimento do trágico:de Schiller a Nietzsche. Rio de Janeiro: Jorge Zahar, 2006.

MORGENSTERN, M. Schopenhauers Begriff der Metaphysik und seine Bedeutung für die Philosophie des 19. Jahrhunderts. Zeitschrift für Philosophische Forschung, Bd41, H. 4, p. 592-612, Oct./Dec., 1987.

NIGHTINGALE, A. W. Spectacles of truth in classical Greek philosophy: theoria in its cultural context. New York: Cambridge University Press, 2009.

PESSOA, F. O eu profundo e os outros eus. 13. ed. Rio de Janeiro: Nova Fronteira, 1980.

PIEPER, J. Que é filosofar? São Paulo: Loyola, 2014.

PLANT, R. Hegel: sobre religião e filosofia. Tradução de Oswaldo Giacóia. São Paulo: UNESP, 2000.

PLATÃO. Platonis Opera. Tomus II. Organized by John Burnet. New York: Oxford University Press, First Published 1901.

. Platonis Opera. Tomus IV Organized by John Burnet. New York: Oxford University Press, First Published 1902. 
Platonis Opera. Tomus III. Organized by John Burnet. New York: Oxford University Press, First Published 1903.

. Platonis Opera. Tomus I. Organized by E. A. Duke et al. New York: Oxford University Press, 1995.

PRADEAU, J.-F. Platão, antes da invenção da paixão. In: BESNIER, B.; MOREAU, P.-F.; RENAULT, L. (org.). As paixóes antigas e medievais: teorias e críticas das paixões. São Paulo: Loyola, 2008. p. 23-36.

REALE, G. História da filosofia antiga. São Paulo: Loyola, 1993.

ROSTAND, F. Schopenhauer et les démonstrations mathématiques. Revue d'Histoire des Sciences et de Leurs Applications, v. 6, n. 3, p. 203-230, Juil./Sept. 1953.

RUBINELLI, S. Ars topica: the classical technique of constructing arguments from Aristotle to Cicero. Netherlands: Springer, 2009.

SCHMITT, A. Poetik: Übersetzt und erläutert von Arbogast Schmitt. Berlin: Akademie Verlag, GmbH, 2012.

SCHOPENHAUER, A. Über das metaphysische Bedürfnis des Menschen. In: Die Welt als Wille und Vorstellung II. Sämtliche Werke. Band II. Stuttgart; Frankfurt am Main: Suhrkamp Taschenbuch Wissenschaft, 1989a. p. 206-241.

. Über den Tod und sein Verhältnis zur Unzerstörbarkeit unsers Wesens an sich. In: Die Welt als Wille und Vorstellung II. Sämtliche Werke. Band II. Stuttgart; Frankfurt am Main: Suhrkamp Taschenbuch Wissenschaft, 1989b. p. 590-651.

. Die Welt als Wille und Vorstellung I. Sämtliche Werke. Band II. Sttugart; Frankfurt am Main: Suhrkamp Taschenbuch Wissenschaft, 1991.

. Crítica da filosofia kantiana. Tradução de Maria L. M. O. Cacciola. In: Schopenhauer. São Paulo: Nova Cultural, 1997. p. 117-235. (Os Pensadores).

. Aforismos para sabedoria de vida. São Paulo: Martins Fontes, 2002.

. Fragmentos para a história da filosofia. Tradução de Maria L. Cacciola. São Paulo: Iluminuras, 2003.

Sobre a necessidade metafísica da humanidade. In: SCHOPENHAUER, A. $O$ mundo como vontade e representação. Tomo II. Complementos. Livros I -II. Volume 1. Tradução de Eduardo Ribeiro da Fonseca. Curitiba: UFPR, 2014a. p. 249-285.

. Sobre a morte e sua relaçáo com a indestrutibilidade do nosso ser-em-si. In: SCHOPENHAUER, A. O mundo como vontade e representaçâo. Tomo II. Complementos. Livros III -IV. Volume 2. Tradução de Eduardo Ribeiro da Fonseca. Curitiba: UFPR, 2014b. p. 151-211.

. Sobre a história. In: SCHOPENHAUER, A. O mundo como vontade e representação. Tomo II. Complementos. Livros III -IV. Volume 2. Tradução de Eduardo Ribeiro da Fonseca. Curitiba: UFPR, 2014c. p. 117-129. 
SCHÖNDORF, H. La muerte en la filosofía de Arthur Schopenhauer. Revista Portuguesa de Filosofia, t. 65, O Dom, a Verdade, e a Morte: Abordagens e Perspectivas/The Gift, Truth, and Death: Approaches and Perspectives, p. 1193- 1204, 2009.

SNELL, B. A cultura grega e as origens do pensamento europeu. São Paulo: Perspectiva, 2001.

SZONDI, P. Ensaio sobre o trágico. Rio de Janeiro: Jorge Zahar, 2004. 
ENGLER, M. R. 